\title{
Evaluation of Gradation Variation of the Granite Aggregates Used in Asphalt Mixtures at Their Manufacturing Place
}

\author{
Mantas Makulavičius (iD*, Henrikas Sivilevičius \\ Department of Mobile Machinery and Railway Transport, Transport Engineering, \\ Vilnius Gediminas Technical University, Vilnius, Lithuania
}

Received 04 February 2020; accepted 20 April 2020

\begin{abstract}
Asphalt mixture gradation homogeneity is one of the key factors for proper laying and compaction during road pavement and its long-term maintenance afterwards. To achieve the good quality asphalt mixture homogeneity of aggregates used in road pavement must be kept in mind. Regarding to this, gradation variation of five different granite aggregates fractions $(0 / 2,2 / 5,5 / 8,8 / 11$ and 11/16) from one of the largest manufacturing plants in Lithuania were determined in this paper. Total of 244 samples were taken from conveyer belt at the manufacturing place and all the data was evaluated by statistical methods providing histograms with theoretical curves of normal distribution. After that, the results were compared to each other and the requirements issued by Lithuanian road administration authority. Regression analysis was used to determine the dependence of standard deviation of percent passing and the mean percent passing through the sieves. The obtained research findings revealed that the maximum value of standard deviation of this dependence was equal to mean of 50\% percent passing. Further investigations should include other aggregates quality parameters variation and its homogeneity throughout different stages of technological and transportation processes.
\end{abstract}

Keywords: aggregates, homogeneity, granite, gradation, variation, conveyor belt, fractions, mineral materials, standard deviation.

\section{Introduction}

In most countries, the pavement of roads is made of bituminous mixes, with hot-mix asphalt (HMA) mixture being the most popular material due to its numerous advantages (Hunter, 1997; Roberts et al., 1991). Lithuania is not an exception. According to 2019-01-01 data provided by Lithuanian Road Administration and evaluating all the road network of national significance $(21237.637 \mathrm{~km})$ more than 69 percent of roads are paved with bituminous mixes. Although more than 30 percent of national significance road network is paved with unbound mixtures, all of these in regional roads category.

Asphalt mixtures used in road pavements are complex materials, consisting of aggregates, mineral filler and bituminous binder interaction. Keeping in mind, that almost 95 percent of the mixture weight is made by weight of coarse and fine aggregates, quality parameters of aggregates highly affects the final quality and characteristics of asphalt mixture itself. The properties of aggregates used in HMA have a significant influence on the engineering properties of the pavement in which they are used (Dondi et al., 2012). The composition and physical and mechanical properties of asphalt concrete largely depend on the amount of its components. The optimal amounts of mineral components of asphalt concrete, such as coarse aggregate, fine aggregate, mineral filler and bitumen, are found by using deterministic methods, based on various principles (Vislavičius \& Sivilevičius, 2013). Asphalt is composed of discrete particles, so the homogeneity of asphalt mixtures can directly affect the overall properties of the pavement. The mechanical properties of a bituminous mixture strongly depend on the gradation of the aggregate that represents the mineral skeleton of the mixture (Liu et al., 2014).

The gradation of the combined aggregate in an HMA mixture significantly affects the performance of the HMA pavement. Aggregate gradation and size influence HMA performance parameters such as permanent deformation and fatigue cracking. The degree of homogeneity of the asphalt mixture is an important indicator of the quality of the pavement (Cross \& Brown, 1993; Stroup-Gardiner \& Brown, 1999). It is also believed that the homogeneity of the asphalt concrete plays an important role in influencing its performance and the property homogeneity is attributed to its inner components, including the mechanical and morphological characteristics of the void, asphalt binder and aggregates respectively (Ding et al., 2018). The homogeneity of HMA mostly decreases due to the segregation

*Corresponding author. E-mail: m.makulavicius@gmail.com

\section{Copyright (C) 2020 The Author(s). Published by VGTU Press}

This is an Open Access article distributed under the terms of the Creative Commons Attribution License (http://creativecommons.org/licenses/by/4.0/), which permits unrestricted use, distribution, and reproduction in any medium, provided the original author and source are credited. 
processes during storage, transportation, laying and compacting (Sivilevičius \& Vislavičius, 2008). During this research, the main aim is to determine and evaluate gradation variation and homogeneity of granite aggregates used in asphalt pavement at the manufacturing place. Firstly, technical requirements analysis is conducted to be able compare obtained results further on.

\section{Analysis of the technical requirements for aggregates according to Lithuanian Road administration}

Aggregates quality requirements are described in various Lithuanian and European standards, such as:

- LST EN 13043:2003 Aggregates for bituminous mixtures and surface treatments for roads, airfields and other trafficked areas;

-LST EN 13242:2003+A1:2008 Aggregates for unbound and hydraulically bound materials for use in civil engineering work and road construction;

-LST EN 12620:2003+A1:2008 Aggregates for concrete;

-LST EN 13450:2003 Aggregates for railway ballast.

Respectively to fulfill these standards Lithuania Road Administration issue technical requirements documents, in which specific parameters for aggregates are described rather than general norms. TRA UZPILDAI 19 is currently in effect (issued 201906 17). New document changed TRA MIN 07 issue, which with several additions had been valid for more than 12 years since 2007.

The purpose of the technical requirements document is to specify, within the categories specified in the standards, the specific requirements for aggregates according to their field of application. While analyzing the documents, requirements related to the subject matter (grading and fine particle content) for aggregates used in road bituminous mixtures were taken into consideration.

After comparative analysis of the specifications, the table below shows the differences in grading requirements for the aggregates used in road bituminous mixtures:

Table 1. Comparison analysis of technical requirements for aggregates granulometry (source: Author, 2020)

\begin{tabular}{|c|c|c|c|c|c|c|c|}
\hline \multirow{3}{*}{$\begin{array}{l}\text { Technical requirements } \\
\text { document issue }\end{array}$} & \multirow{3}{*}{$\begin{array}{c}\text { Particle size fraction } \\
\mathrm{d} / \mathrm{D} \\
\mathrm{mm} / \mathrm{mm}\end{array}$} & \multirow{3}{*}{$\begin{array}{c}\text { Category } \\
\mathrm{G} \\
\end{array}$} & \multicolumn{5}{|c|}{ Passing particle weight percentage } \\
\hline & & & \multirow{2}{*}{$2 \mathrm{D}$} & \multirow{2}{*}{$1,4 \mathrm{D}$} & \multirow{2}{*}{$\mathrm{D}$} & \multirow{2}{*}{$\mathrm{d}$} & \multirow{2}{*}{$\mathrm{d} / 2$} \\
\hline & & & & & & & \\
\hline \multirow{5}{*}{ TRA UZPILDAI 19} & $0 / 2$ & GF85 & 100 & - & $85-99$ & - & - \\
\hline & $2 / 5$ & GC90/10 & 100 & 100 & $90-99$ & $0-10$ & $0-2$ \\
\hline & $5 / 8$ & GC90/20 & 100 & $98-100$ & $90-99$ & $0-20$ & $0-5$ \\
\hline & $8 / 11$ & GC90/20 & 100 & $98-100$ & $90-99$ & $0-20$ & $0-5$ \\
\hline & $11 / 16$ & GC $90 / 20$ & 100 & $98-100$ & $90-99$ & $0-20$ & $0-5$ \\
\hline \multirow{5}{*}{ TRA MIN 07} & $0 / 2$ & GF85 & 100 & - & $85-99$ & - & - \\
\hline & $2 / 5$ & GC90/10 & 100 & 100 & $90-99$ & $0-10$ & $0-2$ \\
\hline & $5 / 8$ & GC90/15 & 100 & $98-100$ & $90-99$ & $0-15$ & $0-5$ \\
\hline & $8 / 11$ & GC90/15 & 100 & $98-100$ & $90-99$ & $0-15$ & $0-5$ \\
\hline & $11 / 16$ & GC90/15 & 100 & $98-100$ & $90-99$ & $0-15$ & $0-5$ \\
\hline
\end{tabular}

From the data in the table, we can state that the updated requirements for the aggregates used in bituminous mixtures have decreased by quality perspective. The general requirements for grading for fractions 5/8, 8/11 and 11/16, where the weight percentage of the passing particles on the $d$ sieve can be higher by 5 percentage points (increased from $0-15$ to $0-20$ ). This means these fractions have broader variation possibility and less homogeneity. However, these requirements do not forbid the manufacturer produce higher category aggregates as it was described in previous technical requirements.

While evaluating the requirements for the content of fines (finest aggregate particles passing through a $0.063 \mathrm{~mm}$ mesh sieve), it can be concluded that for aggregates used in road bituminous mixtures they remain unchanged after issuing new technical requirements document and are provided in the table below.

Table 2. Content of fines requirements for aggregates used in road bituminous mixtures (source: TRA UZPILDAI, 2019)

\begin{tabular}{|l|c|c|c|c|c|c|}
\hline \multicolumn{1}{|c|}{ Fraction } & $0 / 2$ & $2 / 5$ & $5 / 8$ & & $8 / 11$ & $11 / 16$ \\
\hline Fines content category & f16 & f2 & f2 & & f2 & f1 \\
\hline Aggregate particles passing through a $0.063 \mathrm{~mm}$ mesh sieve weight percentage & $\leq 16$ & $\leq 2$ & $\leq 2$ & $\leq 2$ & $\leq 1$ \\
\hline
\end{tabular}




\section{Investigation of granite aggregates gradation variation}

Due to geographical placement of Lithuania, there is no opportunity to extract granite aggregates according to economical rationality. Although there are resources of surface boulders, which were crushed and aggregates produced during the soviet occupation times. Nowadays one of the biggest Lithuania granite resources lies at southeast Lithuania in Marcinkoniai granitoid resources field, which area is about $300 \mathrm{sq}$. km, but granite lies here at 200-300 m deep (Vaitkevičius \& Deltuva, 2006). Linking to this, all aggregates of magmatic origin used in Lithuania are either imported as products either as raw material for further production from Scandinavia, Belarus, Ukraine natural resources quarries. There are more than 8 granite aggregates manufacturing plants in Lithuania, which take raw material and crush, screen and produce final product according to valid Lithuanian standards and requirements.

For research purposes, one of the biggest of them was chosen. Manufacturing plant which is in Vilnius is capable to produce more than 400 thousand tons of granite aggregates annually. While possibilities to produce different fractions of aggregates are quite wide, 5 standard fractions used in asphalt mixtures were selected (0/2, 2/5, 5/8, 8/11, $11 / 16 \mathrm{~mm}$ ). Total of 244 samples were collected from conveyer belts at the manufacturing plant stage F (Figure 1).

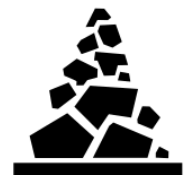

A

Raw material stockpiles (fr. 20/40 mm)

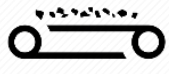

B

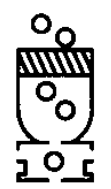

C

Cone crusher

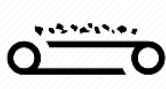

D

Conveying

Conveying

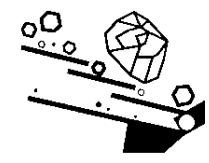

E

Screening

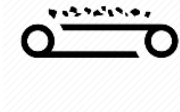

F

Conveying

(Sampling place)

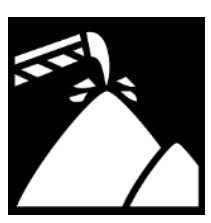

G

Final production stockpiles

Figure 1. Schematic technology stages for aggregates production

Granite aggregates are produced from raw material fraction $20 / 40 \mathrm{~mm}$. From the raw material stockpile, material is transported to the cone crusher and crushed with various closed side setting parameters depending on the production (up to 16 or up to $11 \mathrm{~mm}$ ). After the cone crusher all the material is transported to the final screening process, consisting of 5 different vibrating screens, where oversized material goes back to the cone crusher and screened final products are then transported by conveyor belts to final production stockpiles.

All the collected samples were sieved using sieves according to TRA UZPILDAI 19 requirements (Table 3) for sieve mesh size and then gradation and percentage of fines were determined.

Table 3. Sieve mesh sizes in millimeters used in determining aggregates gradation (source: Author, 2020)

\begin{tabular}{|c|c|c|c|c|c|c|c|c|c|c|c|c|}
\hline \multicolumn{10}{|c|}{ Sieve mesh size, mm } \\
\hline 0,063 & 1 & 2 & 4 & $\begin{array}{r}5,6 \\
(5)\end{array}$ & 8 & $\begin{array}{r}11,2 \\
(11)\end{array}$ & 16 & $\begin{array}{c}22,4 \\
(22)\end{array}$ & $\begin{array}{c}31,5 \\
(32)\end{array}$ & 45 & 56 & 63 \\
\hline
\end{tabular}

After the determination of aggregate grading in laboratory, gradation curves for each fraction were obtained and later analyzed by statistical parameters. Material gradation can be expressed in terms of partial percent of aggregate retained in the sieves, cumulative percent of aggregate retained in the sieves and percent of aggregate passing through the sieves. Therefore, the arithmetic mean, calculated for each sieve by each of those three methods, differs. Usually, gradation of aggregate or aggregate mixture is expressed in percent passing through the sieves (Navikas et al., 2016). Statistical indicators of percent passing of the granite aggregates through separate laboratory sieves, histograms and theoretical curves of normal distribution are presented in Figure 2 below.

It can be stated that biggest standard deviation parameter is at interim sieve mesh for fractions $0 / 2 \mathrm{~mm}$ and $2 / 5$ (4.655 at sieve size $1 \mathrm{~mm}$ and 10.148 at sieve size $4 \mathrm{~mm}$ accordingly). These values together with standard deviation for faction $5 / 8 \mathrm{~mm}$ at sieve size $5.6 \mathrm{~mm}$ (value of 6.462) are the biggest through all the evaluation. Standard deviation for all the fractions except fraction $0 / 2$ is relatively small for contents of fine, meaning all these fractions are screened effectively for fine particles content. 


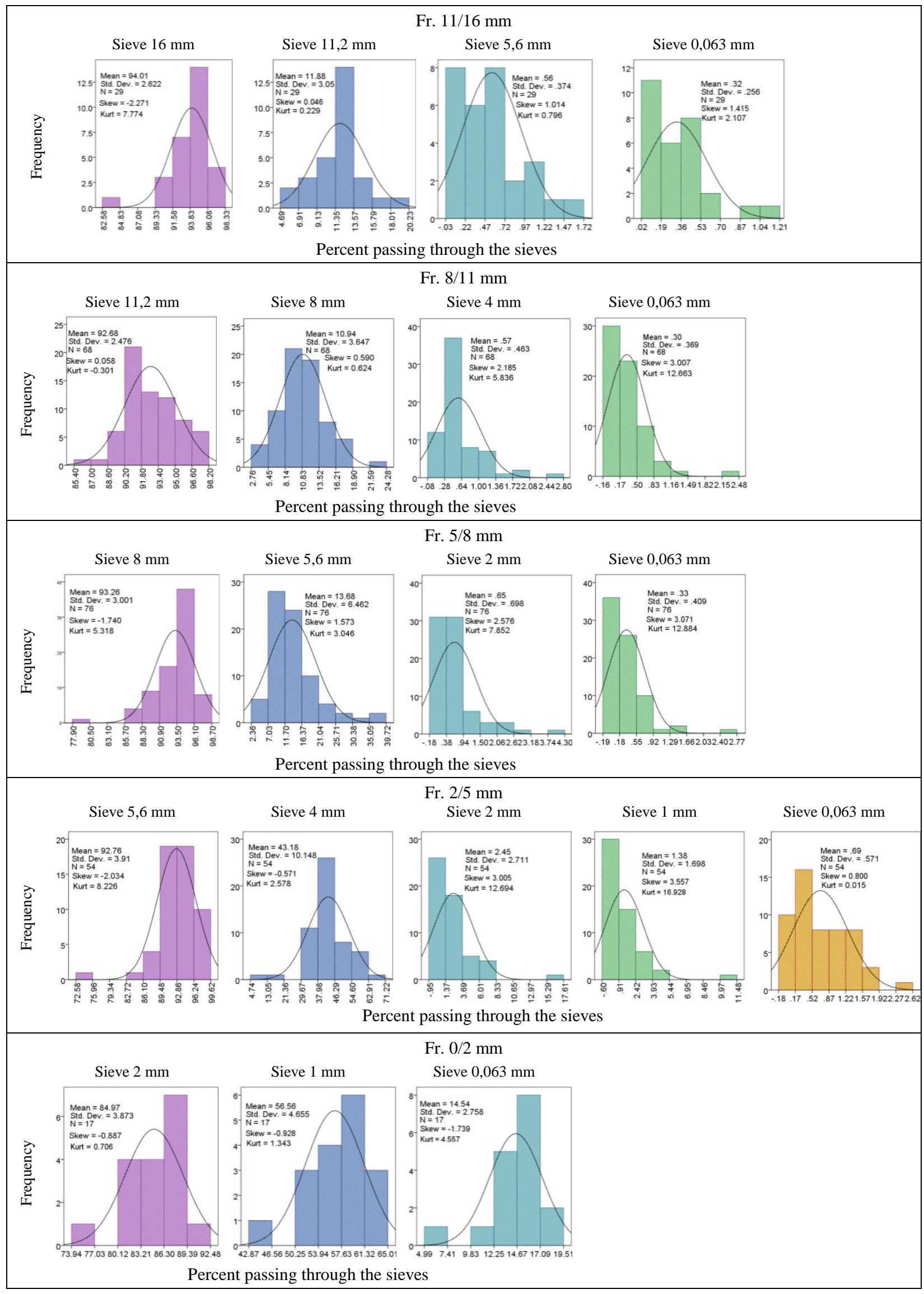

Figure 2. Histograms and statistical indicators for each produced aggregates fraction 


\section{Evaluation of granite aggregates gradation variation and homogeneity}

The grading of each fraction produced was evaluated separately. The arithmetic mean, standard deviation, skewness and kurtosis of each fraction are provided in the table below.

Table 4. Statistical parameters analysis of each fraction gradation (source: Author, 2020)

\begin{tabular}{|c|c|c|c|c|c|c|c|}
\hline Fraction, $\mathrm{mm}$ & $\mathrm{N}$ & Sieve size, $\mathrm{mm}$ & Mean & St. Dev. & $\mathrm{N}$ & Skew & Kurt \\
\hline \multirow{4}{*}{$11 / 16$} & \multirow{4}{*}{29} & 16 & 94.01 & 2.622 & 29 & -2.271 & 7.774 \\
\hline & & 11.2 & 11.88 & 3.05 & 29 & 0.046 & 0.229 \\
\hline & & 5.6 & 0.56 & 0.374 & 29 & 1.014 & 0.796 \\
\hline & & 0.063 & 0.32 & 0.256 & 29 & 1.415 & 2.107 \\
\hline \multirow{4}{*}{$8 / 11$} & \multirow{4}{*}{68} & 11.2 & 92.68 & 2.476 & 68 & 0.058 & -0.301 \\
\hline & & 8 & 10.94 & 3.647 & 68 & 0.59 & 0.624 \\
\hline & & 4 & 0.57 & 0.463 & 68 & 2.185 & 5.836 \\
\hline & & 0.063 & 0.3 & 0.369 & 68 & 3.007 & 12.663 \\
\hline \multirow{4}{*}{$5 / 8$} & \multirow{4}{*}{76} & 8 & 93.26 & 3.001 & 76 & -1.74 & 5.318 \\
\hline & & 5.6 & 13.68 & 6.462 & 76 & 1.573 & 3.046 \\
\hline & & 2 & 0.65 & 0.698 & 76 & 2.576 & 7.852 \\
\hline & & 0.063 & 0.33 & 0.409 & 76 & 3.071 & 12.884 \\
\hline \multirow{5}{*}{$2 / 5$} & \multirow{5}{*}{54} & 5.6 & 92.76 & 3.91 & 54 & -2304 & 8.226 \\
\hline & & 4 & 43.18 & 10.148 & 54 & -0.571 & 2.578 \\
\hline & & 2 & 2.45 & 2.711 & 54 & 3.005 & 12.694 \\
\hline & & 1 & 1.38 & 1.698 & 54 & 3.557 & 16.928 \\
\hline & & 0.063 & 0.69 & 0.571 & 54 & 0.8 & 0.015 \\
\hline \multirow{3}{*}{$0 / 2$} & \multirow{3}{*}{17} & 2 & 84.97 & 3.873 & 17 & -0.887 & 0.706 \\
\hline & & 1 & 56.56 & 4.655 & 17 & -0.928 & 1.343 \\
\hline & & 0.063 & 14.54 & 2.758 & 17 & -1.739 & 4.557 \\
\hline
\end{tabular}

Comparing the obtained statistical parameters from Table 4 with the requirements of the Lithuanian Road Administration for the mineral materials used in bituminous mixtures for roads, it can be concluded that the average values of all fractions produced by both production sites meet the requirements for both gradation and fine particle content. The variation of gradation of granular material or aggregate mixture was suggested (Mucinis et al., 2009) to be determined based on the max value of percent passing $s_{\text {pmax }}$.

Afterwards gradation variation is calculated and expressed by standard deviations $s_{p}$ of percent passing through all screens. Their values depend on means p of percent passing and the homogeneity of the material (Navikas et al., 2018). It is recommended to evaluate the variation of crushed granite according to value of the maximum percent passing through sieves. Correlation $s_{-} p=f(p)$, obtained from the experimental investigation of the gradation enables to calculate $s_{\text {pmax }}$ of aggregate gradation, not taking into consideration the mesh size of the laboratory sieves used. Standard deviation of percent passing varies depending on the means according to the following regression model:

$$
s_{p}=\sqrt{a \cdot \bar{p}^{b} \cdot(100-\bar{p})^{c}}
$$

where: $a, b, c$ - unknown parameters of the model (regression coefficient), influencing on the shape and asymmetry of the curve; $s_{p}$-standard deviation of percent passing through any sieve, $\% ; p$-mean percent passing through this sieve. The model indicates that maximum $s_{\text {pmax }}$ occurs in the particles the content of which in material accounts for $50 \%$ of its mass. For each produced fraction homogeneity regression equations were obtained (Figure 3).

The values of determination coefficient close to 1 , indicate that the variance of standard deviation $s_{p}$ of all material percent passing through sieves is close to $100 \%$ influenced by the variation of mean $p$. It follows that the obtained regression equations are reliable, and its calculated ordinates indicate strong correlation between the characteristics of each gradation and may be used to evaluate the homogeneity of the gradation of different fraction produced in different locations. 


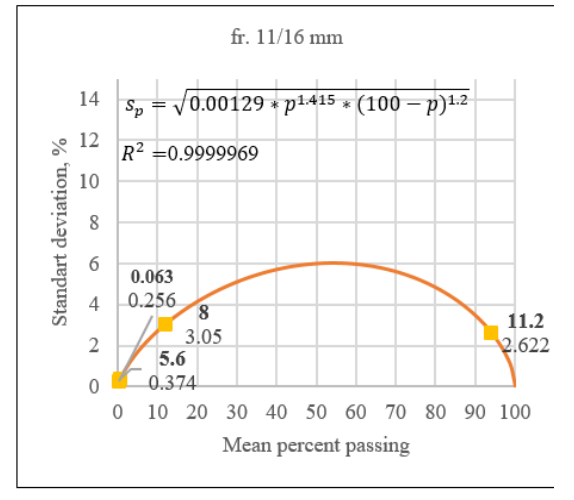

a)

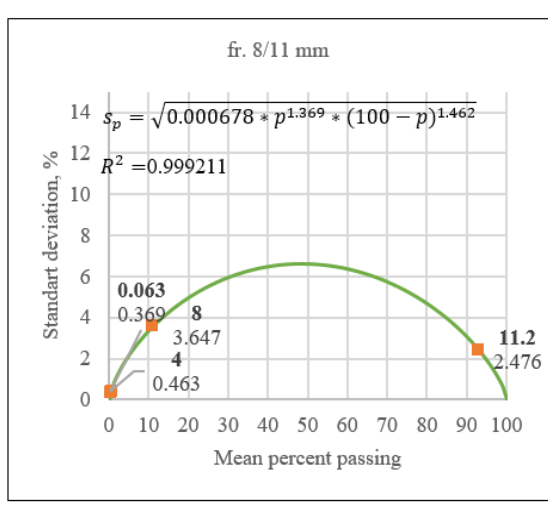

b)

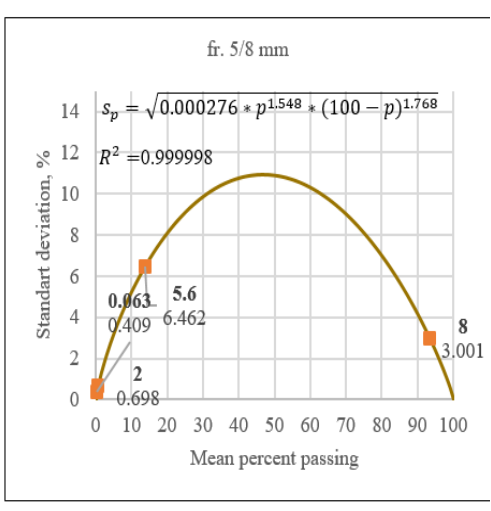

c)

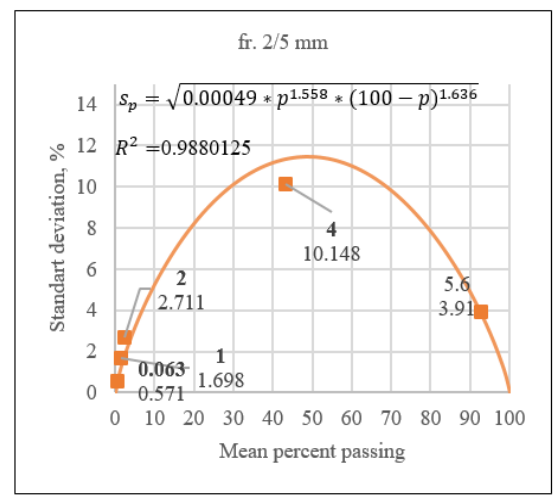

d)

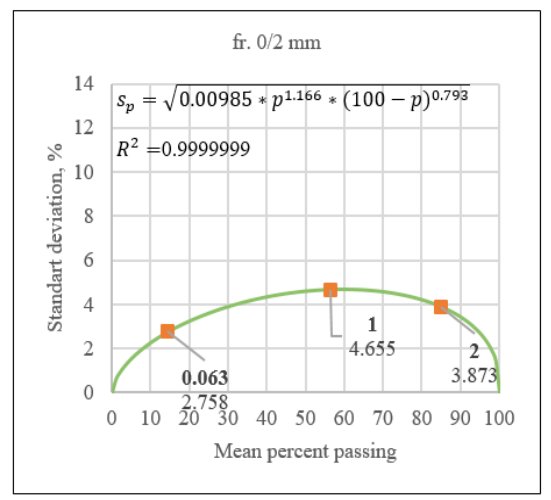

e)

Figure 3. Homogeneity regression equations and graphs for all the produced aggregates fractions

Afterwards the normality hypothesis was checked evaluating kurtosis and skewness parameters of each gradation according to formulas below:

$$
\begin{gathered}
s_{s k}=\sqrt{\frac{6 n(n-1)}{(n-2)(n+1)(n+2)}} ; \\
s_{k u}=\sqrt{\frac{24(n-1)^{2}}{(n-3)(n-2)(n+3)(n+5)}},
\end{gathered}
$$

where $n$ - the sample size (number of measurements). When $|s k|<3 \mathrm{~s}_{\mathrm{sk}}$ and $|k u|<5 \mathrm{~s}_{\mathrm{ku}}$, it can be considered that the normality hypothesis of empirical data is accepted. All the calculations and results are provided in the Table 5.

\begin{tabular}{|c|c|c|c|c|c|c|c|}
\hline \multirow{2}{*}{ Fraction, mm } & \multirow{2}{*}{ Sieve size, $\mathrm{mm}$} & \multicolumn{6}{|c|}{ Normality testing } \\
\hline & & $\mathrm{S}_{\mathrm{sk}}$ & $3 \mathrm{~S}_{\mathrm{sk}}$ & $+1-$ & $\mathrm{S}_{\mathrm{ku}}$ & $5 \mathrm{~S}_{\mathrm{ku}}$ & $+1-$ \\
\hline \multirow{4}{*}{$11 / 16$} & 16 & 0.464 & 1.391 & 1 & 0.902 & 4.509 & 1 \\
\hline & 11.2 & 0.464 & 1.391 & 1 & 0.902 & 4.509 & 1 \\
\hline & 5.6 & 0.464 & 1.391 & 1 & 0.902 & 4.509 & 1 \\
\hline & 0.063 & 0.464 & 1.391 & 1 & 0.902 & 4.509 & 1 \\
\hline \multirow{4}{*}{$8 / 11$} & 11.2 & 0.340 & 1.019 & 1 & 0.668 & 3.340 & 1 \\
\hline & 8 & 0.340 & 1.019 & 1 & 0.668 & 3.340 & 1 \\
\hline & 4 & 0.340 & 1.019 & 0 & 0.668 & 3.340 & 0 \\
\hline & 0.063 & 0.340 & 1.019 & 0 & 0.668 & 3.340 & 0 \\
\hline
\end{tabular}

Table 5. Statistical parameters for normality test analysis of each fraction gradation (source: Author, 2020) 
End of Table 5

\begin{tabular}{|c|c|c|c|c|c|c|c|}
\hline \multirow{2}{*}{ Fraction, $\mathrm{mm}$} & \multirow{2}{*}{ Sieve size, $\mathrm{mm}$} & \multicolumn{6}{|c|}{ Normality testing } \\
\hline & & $\mathrm{S}_{\mathrm{sk}}$ & $3 \mathrm{~S}_{\mathrm{sk}}$ & $+/-$ & $\mathrm{S}_{\mathrm{ku}}$ & $5 S_{\mathrm{ku}}$ & $+1-$ \\
\hline \multirow{4}{*}{$5 / 8$} & 8 & 0.322 & 0.965 & 1 & 0.634 & 3.168 & 1 \\
\hline & 5.6 & 0.322 & 0.965 & 0 & 0.634 & 3.168 & 1 \\
\hline & 2 & 0.322 & 0.965 & 0 & 0.634 & 3.168 & 0 \\
\hline & 0.063 & 0.322 & 0.965 & 0 & 0.634 & 3.168 & 0 \\
\hline \multirow{5}{*}{$2 / 5$} & 5.6 & 0.369 & 1.108 & 0 & 0.724 & 3.622 & 0 \\
\hline & 4 & 0.369 & 1.108 & 0 & 0.724 & 3.622 & 0 \\
\hline & 2 & 0.369 & 1.108 & 1 & 0.724 & 3.622 & 1 \\
\hline & 1 & 0.369 & 1.108 & 0 & 0.724 & 3.622 & 0 \\
\hline & 0.063 & 0.369 & 1.108 & 0 & 0.724 & 3.622 & 0 \\
\hline \multirow{3}{*}{$0 / 2$} & 2 & 0.393 & 1.178 & 1 & 0.768 & 3.840 & 1 \\
\hline & 1 & 0.393 & 1.178 & 1 & 0.768 & 3.840 & 1 \\
\hline & 0.063 & 0.393 & 1.178 & 1 & 0.768 & 3.840 & 1 \\
\hline
\end{tabular}

Values of 1, shows that normality hypothesis of empirical data is accepted. Value of 0 , that it is declined. Evaluating the analysis, it can be stated that both kurtosis and skewness parameters normality conditions for fractions $11 / 16$ and $0 / 2$ is fulfilled. Other fractions show fragmentated results depending on the sieve size.

To check if there is any statistical difference in the variances for different granite aggregates fractions, the Bartlett's criterion was used:

$$
B=\frac{E}{C}=\frac{2.303\left[k \cdot \log _{10} \bar{s}^{2}-\sum_{i=l}^{l} k_{i} \log _{10} s_{i}^{2}\right]}{1+\frac{1}{3(l-1)}\left[\sum_{i=l}^{l} \frac{1}{k_{i}}-\frac{1}{k}\right]},
$$

where: $l$ - the number of different fractions (in this research $l=5$ ); $k_{i}=n_{i}-1$ the number of freedom degrees; $\mathrm{n}_{\mathrm{i}}-$ the number of analyzed samples of the different fractions (in this research 244); $s_{i}^{2}$ - the shift variance of percent passing through the sieves of the $i$-th fraction; $s_{i}-$ its standard deviation; $\mathrm{s}^{2}-$ the weighted mean of variances in all samples taken. The above criterion is considered suitable for checking the uniformity of variances since the size of samples is different. After making the calculations B value is equal to 35.108 , which is higher than $\chi^{2}(0.05 ; 4)=9.488$, so we can conclude that researched aggregates, given the assumed level of significance $\alpha=0.05$, fractions differ statistically and are not homogenous.

\section{Conclusions}

Since HMA quality is affected by its gradation, which eventually is very dependent not only due to the segregation processes during storage, transportation, laying and compacting, but also to the gradation of aggregates itself. All the collected data due to its big sample size and different manufacturing places is very valuable to evaluate produced aggregates gradation homogeneity at the manufacturing place.

Comparing the obtained statistical parameters with the requirements of the Lithuanian Road Administration for the mineral materials used in bituminous mixtures for roads, it can be concluded that the average values of all fractions produced by both production sites meet the requirements for both gradation and fine particle content. It can be stated that biggest standard deviation parameter is at interim sieve mesh for fractions $0 / 2 \mathrm{~mm}$ and $2 / 5 \mathrm{~mm}$. The obtained research findings revealed that the maximum value of standard deviation of this dependence was equal to mean of $50 \%$ percent passing and varied from 4.6 up to 11.4 percent for different fractions. After calculating Bartlett's criteria, which obtained value was higher than $\chi^{2}$, it can be stated that different fractions differ statistically and are not homogenous.

Since the requirements for the aggregates used in bituminous mixtures have decreased by quality perspective with the new technical requirements documents issue in Lithuania, with wider ranges for variation gradation homogeneity of aggregates and HMA itself could decrease. Linking to this quality of HMA homogeneity should be kept in mind and requirements should be reviewed if quality decrease would be noticed. Further investigations should not only include quality inspection but also homogeneity of different aggregates quality parameters and different stages of technological and transportation processes. 


\section{References}

Cross, S. A., \& Brown, E. R. (1993). Effect of segregation on performance of hot-mix asphalt (Transportation Research Record, 1417, pp. 117-126). Transportation Research Board.

Mucinis, D., Sivilevicius, H., \& Oginskas, R. (2009). Factors determining the inhomogeneity of reclaimed asphalt pavement and estimation of its components content variation parameters. Baltic Journal of Road and Bridge Engineering, 4(2), 69-79.

Ding, X., Ma, T., Zhang, W., Zhang, D., \& Yin, T. (2018). Effects by property homogeneity of aggregate skeleton on creep performance of asphalt concrete. Construction and Building Materials, 171, 205-213. https://doi.org/10.1016/j.conbuildmat.2018.03.150

Dondi, G., Simone, A., Vignali, V., \& Manganelli, G. (2012). Discrete element modelling of influences of grain shape and angularity on performance of granular mixes for asphalts. Procedia - Social and Behavioral Sciences, 53, 399-409. https://doi.org/10.1016/j.sbspro.2012.09.891

Hunter, R. N. (1997). Bituminous mixtures in road construction. London: Thomas Telford.

Lietuvos automobilių kelių direkcija. (2007). Automobilių keliu mineralinių medžiagų techninių reikalavimu aprašas TRA MIN 07. https://www.e-tar.lt/rs/legalact/TAR.660AACC2CBFF/format/ISO_PDF/

Lietuvos automobilių kelių direkcija. (2019). Automobilių kelių užpildų techninių reikalavimų aprašas TRA UŽPILDAI 19. TAR, 2019-06-18, Nr. 9738. https://www.e-tar.lt/portal/lt/legalAct/3bbbe4d0910e11e9ae2e9d61b1f977b3

Lietuvos standartizacijos departamentas. (2003). Aggregates for railway ballast (LST EN 13450:2003).

Lietuvos standartizacijos departamentas. (2004). Aggregates for bituminous mixtures and surface treatments for roads, airfields and other trafficked areas (LST EN 13043:2003).

Lietuvos standartizacijos departamentas. (2008). Aggregates for unbound and hydraulically bound materials for use in civil engineering work and road construction (LST EN 13242:2003+A1:2008).

Lietuvos standartizacijos departamentas. (2009). Aggregates for concrete (LST EN 12620:2003+A1:2008).

Liu, T., Zhang, X. N., Li, Z., \& Chen, Z. Q. (2014). Research on the homogeneity of asphalt pavement quality using X-ray computed tomography (CT) and fractal theory. Construction and Building Materials, 68, 587-598. https://doi.org/10.1016/j.conbuildmat.2014.06.046

Navikas, D., Bulevičius, M., \& Sivilevičius, H. (2016). Determination and evaluation of railway aggregate sub-ballast gradation and other properties variation. Journal of Civil Engineering and Management, 22(5), 699-710. https://doi.org/10.3846/13923730.2016.1177586

Navikas, D., Sivilevičius, H., \& Bulevičius, M. (2018). Investigation and evaluation of railway ballast properties variation during technological processes. Construction and Building Materials, 185, 325-337. https://doi.org/10.1016/j.conbuildmat.2018.07.090

Roberts, F. L., Kandahal, P. S., Brown, E. R., Lee, D. Y., \& Kenedy, T. W. (1991). Hot mix asphalt materials, mixture design, and construction. Maryland: NAPA Education Foundation. 490 p.

Sivilevičius, H., \& Vislavičius, K. (2008). Stochastic simulation of the influence of variation of mineral material grading and dose weight on the homogeneity of hot-mix asphalt. Construction and Building Materials, 22(9), 2007-2014. https://doi.org/10.1016/j.conbuildmat.2007.07.001

Stroup-Gardiner, M., Brown, E. R., \& Law, M. (1999). NCHRP 9-11 Segregation in hot mix asphalt pavements (draft final report). National Center for Asphalt Technology.

Vaitkevičius, V., \& Deltuva, J. (2006). Statybinių nerūdinių medžiagu gavyba, perdirbimas ir naudojimas. Technologija. https://core.ac.uk/download/pdf/51635524.pdf

Vislavičius, K., \& Sivilevičius, H. (2013). Effect of reclaimed asphalt pavement gradation variation on the homogeneity of recycled hot-mix asphalt. Archives of Civil and Mechanical Engineering, 13(3), 345-353. https://doi.org/10.1016/j.acme.2013.03.003 